\title{
Protected areas and
}

\section{regional avian species richness in South Africa}

\author{
Karl L. Evans ${ }^{1, *}$, Ana S. L. Rodrigues ${ }^{2}$, \\ Steven L. Chown ${ }^{3}$ and Kevin J. Gaston ${ }^{1}$ \\ ${ }^{1}$ Biodiversity and Macroecology Group, Department of Animal and \\ Plant Sciences, University of Sheffield, Sheffield S10 2TN, UK \\ ${ }^{2}$ Conservation International, 1919 M Street, NW, Suite 600, \\ Washington, DC 20036, USA \\ ${ }^{3}$ Centre for Invasion Biology, Department of Botany and Zoology, \\ University of Stellenbosch, Private Bag X1, Matieland 7602, South \\ Africa \\ *Author for correspondence (karl.evans@sheffield.ac.uk).
}

Protected areas are generally regarded as essential for the long-term maintenance of biodiversity. Evidence for their effectiveness in this regard is, however, somewhat equivocal. Here, we document the relationship between the proportion of protected land and species richness in a region, both with and without taking spatial variation in environmental energy availability into account. Using the South African avifauna as a case study, we find that total and threatened species richness exhibit modest increases with the proportion of protected land. While the protected area network should be expanded, it is essential that conservation efforts also focus on maintaining biodiversity in the wider unprotected landscape that supports high species richness.

Keywords: birds; conservation; extinction; protected areas; South Africa;

species-energy relationship

\section{INTRODUCTION}

Protected areas are widely recognized as central to strategies for the maintenance of biodiversity (UN 1992). Nonetheless, their effectiveness may be limited. Many studies document the inefficiency of reserve networks in representing biodiversity features (e.g. Rodrigues et al. 2004), the ecological degradation of individual reserves (e.g. Liu et al. 2001; Rao et al. 2002) and their inability to retain all the species that were initially present (e.g. Newmark 1996; Nicholls et al. 1996). There is evidence, however, that protected areas can reduce land clearance rates and other pressures (e.g. Bruner et al. 2001; SánchezAzofeifa et al. 2003; Struhsaker et al. 2005). Little attention has been given to the role of protected areas in preserving a region's species richness (Sinclair et al. 2002). Here, we investigate if a region's species richness is related to its proportion of protected land. As a case study, we use the avifauna of South Africa, a country with a long history of designating protected areas and in which at least $7 \%$ of the land is formally protected, with the majority of reserves located in the

The electronic supplementary material is available at http://dx.doi. org/10.1098/rsbl.2005.0435 or via http://www.journals.royalsoc.ac. uk. savanna and fynbos biomes (WDPA 2004). We do so while taking environmental energy availability into account, which is a dominant ecological factor influencing broad spatial variation in avian species richness in South Africa (van Rensburg et al. 2002).

\section{MATERIAL AND METHODS}

\section{(a) Data}

Distributional data for South African birds were obtained from Harrison et al. (1997). Species presence was recorded on checklists, mainly from 1987 to 1992, in quarter-degree grid cells (ca $676 \mathrm{~km}^{2}$ ). For grid cells with more than 10 checklists, we calculated total and threatened species richness (Barnes 2000); other grid cells were excluded to reduce biases caused by under-sampling. Energy availability was measured using the normalized difference vegetation index (NDVI), a strong correlate of net primary productivity in South Africa (Woodward et al. 2001). We used mean January NDVI averaged between 1982 and 1999 as, compared to other seasonal metrics, it is the strongest predictor of avian species richness (Bonn et al. 2004). The use of NDVI as a predictor also largely takes habitat related differences in species richness into account as it is strongly correlated with biome type $\left(r^{2}=60 \%\right)$, although it is a stronger predictor of species richness than the latter (univariate tests $r^{2}=26$ and $52 \%$, respectively, for biome type and NDVI). The proportion of protected land in each cell (see electronic supplementary material) was obtained by overlapping the quarter-degree grid with all 637 national level protected areas mapped in the world database on protected areas (WDPA 2004).

\section{(b) Analyses}

To reduce heteroscedasticity, species richness was square root transformed and all other variables logarithmically transformed. Protected areas were absent from 736 of 1255 grid cells (figure S1, electronic supplementary material); prior to data transformation 0.0005 was added to each estimate of the proportion of protected land. Relationships between species richness and proportion of protected land were investigated using univariate tests and multiple regression models. The latter were constructed using forwards stepwise selection, with NDVI, the proportion of protected land, the interaction between these variables and cell area as predictors. The interaction term tested if the slope of the species-energy relationship was steeper in areas with more protected land. Analyses are unlikely to be confounded by correlation between energy availability and proportion of protected land as this was weak $\left(r^{2}=6 \%\right)$. Data were analysed (SAS v. 8.2) both with and without grid cells that lacked protected land and using the presence/absence of protected areas as a predictor rather than the proportion of land protected. We used PROC GLM to construct general linear models and PROC MIXED to implement spatial correlation models fitting an exponential spatial covariance matrix to the data (Littell et al. 1996).

\section{RESULTS}

In univariate tests square root transformed total and threatened species richness were positively correlated with log transformed proportion of protected land; relationships were similar between the two groups (table 1a). Using the presence/absence of protected areas as a predictor generated similar results (table $1 b$ ). The explanatory power of the proportion of protected land was reduced when excluding grid cells that lacked protected areas (table $1 a$ ). In multiple regression models, the explanatory power of the interaction between $\log$ transformed proportion of land protected and $\log$ transformed NDVI was weak $\left(r^{2}<1 \%\right)$ and only statistically significant in non-spatial models (table $2 a, b$ ). Across all grid cells the partial $r^{2}$ of $\log$ transformed proportion of protected land was 9 and $6 \%$ for total and threatened species richness, respectively. Using the presence/absence of protected areas as an alternative predictor gave similar results.

\section{DISCUSSION}

Accounting for the principal ecological determinant of species richness, environmental energy, total avian 
Table 1. Univariate regressions between avian species richness in South African quarter degree grid cells and (a) proportion of protected land and $(b)$ presence/absence of protected land. (Species richness and other variables were respectively, square root and log transformed. Spatial model fit is assessed using Akaike information criteria (AIC), values of which are provided for comparison with those in table 2; for a given response variable smaller values indicate a better fit. Positive effects $++++p<0.0001$; factors ${ }^{* * * *} p<0.0001$.)

\begin{tabular}{|c|c|c|c|c|}
\hline (a) response & $\begin{array}{l}\text { cells with no protected } \\
\text { area included? }\end{array}$ & model type & prop. protected land & model fit \\
\hline $\begin{array}{l}\text { total richness } \\
\text { threat. richness }\end{array}$ & $\begin{array}{l}\text { yes } \\
\text { no } \\
\text { yes } \\
\text { no }\end{array}$ & $\begin{array}{l}\text { GLM } \\
\text { spatial } \\
\text { GLM } \\
\text { spatial } \\
\text { GLM } \\
\text { spatial } \\
\text { GLM } \\
\text { spatial }\end{array}$ & $\begin{array}{l}F_{1,1252}=315.0++++ \\
F_{1,1252}=96.4++++ \\
F_{1,516}=6.8++++ \\
F_{1,516}=38.3++++ \\
F_{1,1252}=204.7++++ \\
F_{1,1252}=64.9++++ \\
F_{1,516}=19.9++++ \\
F_{1,516}=38.9++++\end{array}$ & $\begin{array}{l}r^{2}=20.1 \% \\
\text { AIC }=4424.7 \\
r^{2}=1.3 \% \\
\text { AIC }=1877.3 \\
r^{2}=14.1 \% \\
\text { AIC }=2767.6 \\
r^{2}=3.7 \% \\
\text { AIC }=1205.5\end{array}$ \\
\hline (b) response & \multicolumn{3}{|c|}{$\begin{array}{l}\text { presence/absence } \\
\text { of protected land }\end{array}$} & model fit \\
\hline $\begin{array}{l}\text { total richness } \\
\text { threat. richness }\end{array}$ & $\begin{array}{l}\text { GLM } \\
\text { spatial } \\
\text { GLM } \\
\text { spatial }\end{array}$ & & $\begin{array}{l}12.0^{* * * *} \\
8.8^{* * * *} \\
78.6^{* * * *} \\
9.5^{* * * *}\end{array}$ & $\begin{array}{l}r^{2}=19.9 \% \\
\text { AIC }=4447.9 \\
r^{2}=12.5 \% \\
\text { AIC }=2788.6\end{array}$ \\
\hline
\end{tabular}

richness correlated positively with the proportion of protected land across South Africa. In average-sized grid cells with low environmental energy, corresponding to the Succulent and Nama Karoo biomes, richness was predicted to rise from 64 to 85 species as the area protected rose from 0 to $100 \%$. Similarly, at high levels of environmental energy, corresponding to mesic savanna habitats in northeast South Africa, richness was predicted to increase from 213 to 250 species (figure S2, electronic supplementary material). Threatened species exhibited similar trends, with unprotected and fully protected grid cells predicted to contain, respectively, one and two species in lowenergy areas and 13 and 17 species in high-energy areas. Results were similar when using the presence/ absence of protected areas rather than the proportion of protected land, and the explanatory power of the proportion of land protected was reduced when grid cells without protected land were excluded. Our results are thus largely driven by variation in richness between grid cells with and without protected areas, suggesting that even small protected areas can, in the short-term, contribute to maintaining regional diversity.

There is increasing interest in the influence of human activities on macroecological patterns (Gaston 2004). Evidence that the proportion of protected area impacted the form of the species-energy relationship is weak. By contrast, Fairbanks et al. (2002) found that human activities (measured as landscape transformation) significantly influenced South African avian richness. However, this influence declined substantially when the covariation of richness and transformation with underlying environmental variables was accounted for (cf. Chown et al. 2003). Much of the remaining weak effect may have arisen from spatial autocorrelation. Here, the weak effect of protected area on the species-energy relationship disappeared when controlling for spatial autocorrelation.
Total and threatened species richness exhibited similar patterns, implying that avian threatened species are generally not represented in the South African protected area network to a greater extent than nonthreatened ones. This pattern could partly arise from inadequacies in the protected area network (Chown et al. 2003; van Rensburg et al. 2004) and/or the positive linear correlation between threatened and nonthreatened species richness $\left(r^{2}=56 \%, p<0.0001\right)$. Given increasing human population density and continuing habitat degradation in the wider landscape (van Rensburg et al. 2004), a conservative approach that well represents currently unthreatened species within the protected area network may be beneficial.

Avian species richness may increase with increasing proportions of protected land if areas of high richness are more likely to be designated as protected areas. The current South African protected area network was, however, foremost implemented for the conservation of large mammal species (Siegfried 1987), whose occurrence in Africa correlates poorly with avian species richness (Williams et al. 2000). Relationships between richness and amount of protected land may thus be stronger for large mammals than birds. More generally, in South Africa the location of the most species rich grid cells differs, sometimes markedly, between most vertebrate taxa (Lombard 1995) so taxonomic variation in the species richness-protected area relationship may be pronounced.

Species richness may also increase with the amount of protected land because the latter reduces habitat loss and other pressures on biodiversity, thus lowering extinction rates within protected areas (SánchezAzofeifa et al. 1999, 2003; Bruner et al. 2001). For example, $50 \%$ of the species present in protected native vegetation in the Serengeti do not occur in adjacent agricultural areas (Sinclair et al. 2002). We compared how the proportion of protected land was 


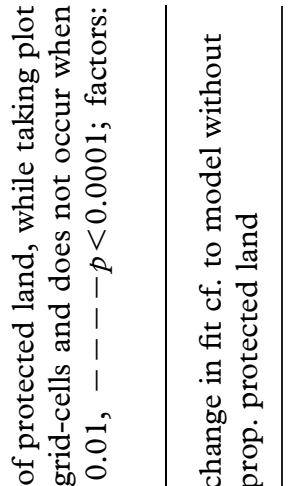

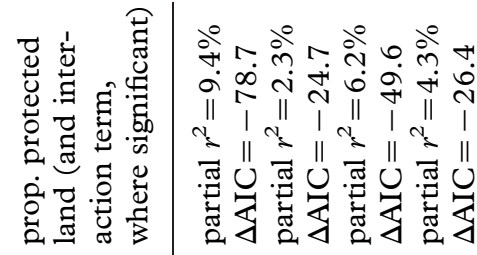

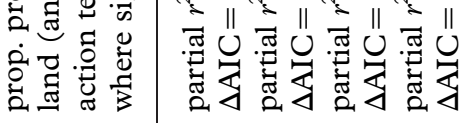

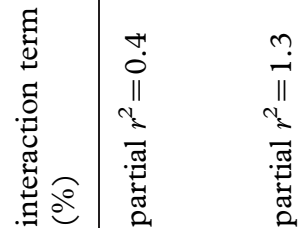

岁岁的

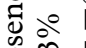

क्ष.

过 范

है \&

焉.

范

형

उ.

造施

행ㅁㅇ

涫宫+

몽

党:

o. 0

कृ

क

离

至

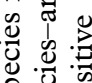

का

ज् के

党

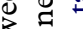

诺

包的

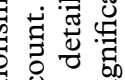

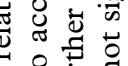

․ㅕㄹ

पै

造完前

表合

远

票䨔

घ 0

है $\bar{g} \mathrm{~V}$

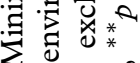

느ํ

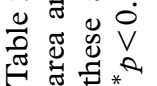

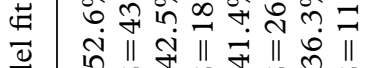

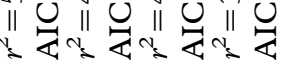

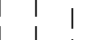

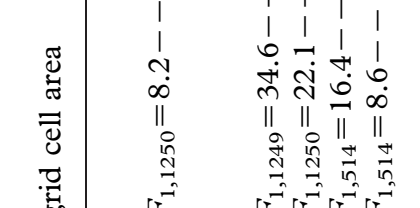

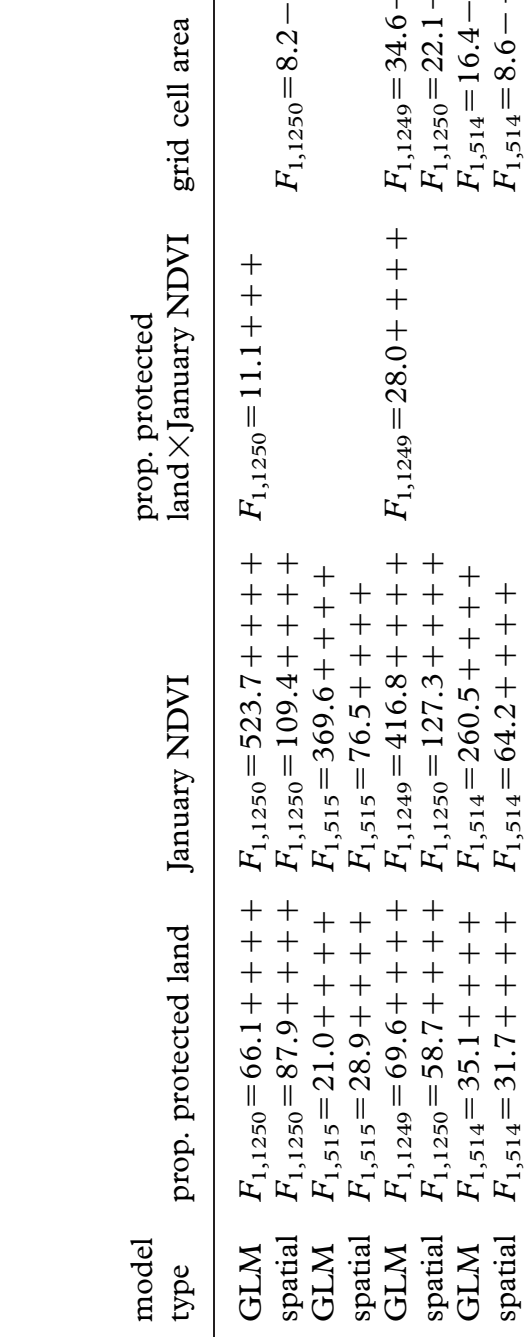

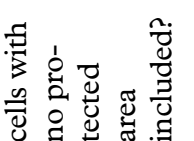

$\stackrel{Ð}{\triangle} \nsubseteq$

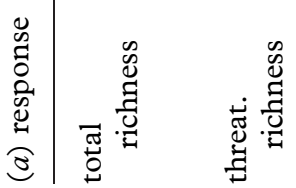

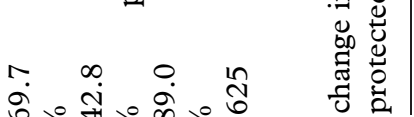

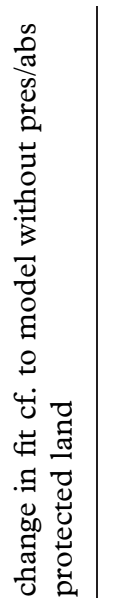

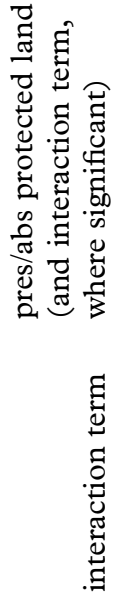

iั่ กุ

$\infty \because \underset{0}{0}$

II I II

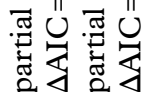

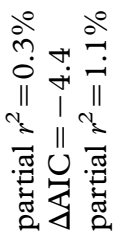

r.

象

in 푸에

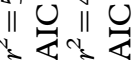

$\ddot{G}$
$\frac{\vec{v}}{8}$
0
$\square$

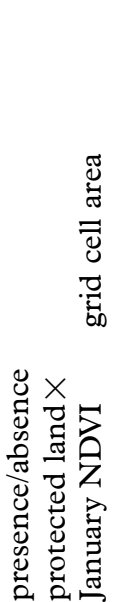

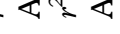

要

$\begin{array}{ccc}1 & 1 & 1 \\ 1 & 1 & 1 \\ -1 & 0\end{array}$

$0 \dot{\infty} \infty$

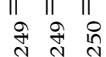

स्ति

* *

से

II II II

in 월

स्ति

$+++$

$+++$

$+++$

完

++++
$+\infty$
$+\infty$

ชิ่

II II ॥

in 의 in

सीस

*

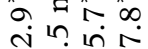

iा

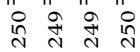

सी

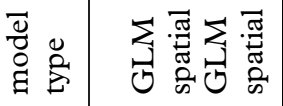

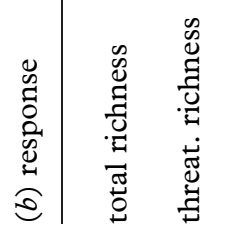


related to land transformation. There is evidence for a constraint relationship, with a high proportion of protection leading to little land transformation, but the trend is not a simple linear one (figure S3, electronic supplementary material), doubtless because many additional historical factors influence land transformation rates. Nonetheless, the relationship indicates that land transformation is more extensive around smaller than larger protected areas, probably because human population densities are higher adjacent to the former (Chown et al. 2003).

Our analyses suggest that in South Africa protected areas have a modest impact on regional avian assemblages, but analyses of spatial variation in species abundances or evenness distributions may reveal stronger impacts (Allan et al. 1997; Fairbanks et al. 2002). It would also be interesting to compare our results to those from other regions as spatial patterns in South African land transformation have been influenced by historical factors that may differ from those elsewhere. The modest nature of the impacts we document may arise from gaps in avian species representation within the current protected area network (Chown et al. 2003; van Rensburg et al. 2004). Alternatively, it may result from: (i) the large spatial scale used and stronger relationships may emerge at finer scales, (ii) the numerous other factors, including the attitudes and activities of local people (such as hunting and agricultural techniques), influencing the conservation of regional species richness, (iii) a weak positive relationship between landscape heterogeneity, resulting from transformation and species richness (Fairbanks et al. 2002), (iv) protected areas acting as sources that maintain the occurrence of species in sink populations (sensu Hanski 1999) outside protected areas or (v) the relatively healthy ecological state of some areas of unprotected land (e.g. 19\% of grid cells with no protected areas contain no transformed land). This suggests that attention be focused on assessing which sections of unprotected and relatively untransformed land should be added to the protected area network; progress has been made in this direction, albeit only for the avifauna (Chown et al. 2003; van Rensburg et al. 2004). It will also be essential to ensure that protected areas are managed to maximize the preservation of their current biodiversity. In addition, it is important that incentives are designed and implemented that encourage environmentally sensitive management of the majority of the unprotected biologically rich landscape.

We thank L. Underhill and the Avian Demography Unit (University of Cape Town) for data access. T. M. Blackburn, S. J. Jackson, M. Greve, D. Spear and D. Storch provided discussion and assistance. The Leverhulme Trust and Centre for Invasion Biology supported this work.

Allan, D. G., Harrison, J. A., Navarro, R. A., van Wilgen, B. W. \& Thompson, M. W. 1997 The impact of commercial afforestation on bird populations in Mpumalanga province,South Africa-insights from bird atlas data. Biol. Conserv. 79, 173-185. (doi:10.1016/S00063207(96)00098-5)
Barnes, K. N. 2000 The Eskom red data book of birds of South Africa, Lesotho and Swaziland. Johannesburg, South Africa: BirdLife South Africa.

Bonn, A., Storch, D. \& Gaston, K. J. 2004 Structure of the species-energy relationship. Proc. R. Soc. B 271, 1685-1691. (doi:10.1098/rspb.2004.2745)

Bruner, A. G., Gullison, R. E., Rice, R. E. \& da Fonseca, G. A. B. 2001 Effectiveness of parks in protecting tropical biodiversity. Science 291, 125-128. (doi:10.1126/ science.291.5501.125)

Chown, S. L., van Rensburg, B. J., Gaston, K. J., Rodrigues, A. S. L. \& van Jaarsveld, A. S. 2003 Energy, species richness, and human population size: conservation implications at a national scale. Ecol. Appl. 13, 1233-1241.

Fairbanks, D. H. K., Kshatriya, M., van Jaarsveld, A. S. \& Underhill, L. G. 2002 Scales and consequences of human land transformation on South African avian diversity and structure. Anim. Conserv. 5, 61-73.

Gaston, K. J. 2004 Macroecology and people. Basic Appl. Ecol. 5, 303-307. (doi:10.1016/j.baae.2004.05.001)

Hanski, I. 1999 Metapopulation ecology. Oxford, UK: Oxford University Press.

Harrison, J. A., Allan, D. G., Underhill, L. G., Herremans, M., Tree, A. J., Parker, V. \& Brown, C. J. 1997 The atlas of southern African birds. Johannesburg, South Africa: BirdLife South Africa.

Littell, R. C., Milliken, G. A., Stroup, W. W. \& Wolfinger, R. D. 1996 SAS system for mixed models. Cary, NC: SAS Institute Inc..

Liu, J., Linderman, M., Ouyang, Z., An, L., Yang, J. \& Zhang, H. 2001 Ecological degradation in protected areas: the case of Wolong Nature Reserve for giant pandas. Science 292, 98-101. (doi:10.1126/science. 1058104)

Lombard, T. M. 1995 The problems with multi-species conservation: do hotspots, ideal and existing reserves coincide. S. Afr. F. Zool. 30, 145-163.

Newmark, W. D. 1996 Insularization of Tanzanian parks and the local extinction of large mammals. Conserv. Biol. 10, 1549-1556. (doi:10.1046/j.1523-1739.1996. 10061549.x)

Nicholls, A. O., Viljoen, P. C., Knight, M. H. \& van Jaarsveld, A. S. 1996 Evaluating population persistence of censused and unmanaged herbivore populations from the Kruger National Park, South Africa. Biol. Conserv. 76, 57-67. (doi:10.1016/0006-3207(95) 00094-1)

Rao, M., Rabinowitz, A. \& Khaing, S. T. 2002 Status review of the protected-area system in Myanmar, with recommendations for conservation planning. Conserv. Biol. 16, 360-368. (doi:10.1046/j.1523-1739.2002. 00219.x)

Rodrigues, A. S. L. et al. 2004 Effectiveness of the global protected area network in representing species diversity. Nature 428, 640-643. (doi:10.1038/ nature 02422)

Sánchez-Azofeifa, G. A., Daily, G. C., Pfaff, A. S. P. \& Busch, C. 2003 Integrity and isolation of Costa Rica's national parks and biological reserves: examining the dynamics of land-cover change. Biol. Conserv. 109, 123-135. (doi:10.1016/S0006-3207(02)00145-3)

Sánchez-Azofeifa, G. A., Quesada-Mateo, C. A., GouzalezQuesada, P., Dayanandan, S. \& Bawa, K. 1999 Protected areas and conservation of biodiversity in the tropics. Cons. Biol. 13, 407-411.

Siegfried, W. R. 1987 To have and to keep. In The National Parks of South Africa (ed. R. Gordon \& A. C. Bannister), pp. 12-17. Cape Town, South Africa: Struik. 
Sinclair, A. R. E., Mduma, S. A. R. \& Arcese, P. 2002 Protected areas as biodiversity benchmarks for human impact: agriculture and the Serengeti avifauna. Proc. R. Soc. B 269, 2401-2405. (doi:10.1098/rspb. 2002.2116)

Struhsaker, T. T., Struhsaker, P. J. \& Siex, K. S. 2005 Conserving Africa's rain forests: problems in protected areas and possible solutions. Biol. Conserv. 123, 45-54. (doi:10.1016/j.biocon.2004.10.007)

UN 1992 Convention on Biological Diversity-United Nations Conf. on Environment and Development. Rio de Janeiro, Brazil: United Nations.

van Rensburg, B. J., Chown, S. L. \& Gaston, K. J. 2002 Species richness, environmental correlates, and spatial scale: a test using South African birds. Am. Nat. 159, 566-577. (doi:10.1086/339464) van Rensburg, B. J., Erasmus, B. F. N., van Jaarsveld, A. S. \& Gaston, K. J. 2004 Conservation during times of change: correlations between birds, climate and people in South Africa. S. Afr. F. Sci. 100, 266-272.

WDPA 2004 World database on protected areas. Washington, DC: IUCN-WCPA and UNEP-WCMC.

Williams, P. H., Burgess, N. D. \& Rahbek, C. 2000 Flagship species, ecological complementarity and conserving the diversity of mammals and birds in sub-Saharan Africa. Anim. Conserv. 3, 249-260. (doi:10.1017/ S1367943000000974)

Woodward, F. I., Lomas, M. R. \& Lee, S. E. 2001 Predicting the future production and distribution of global terrestrial vegetation. In Terrestrial global productivity (ed. J. Roy, B. Saugier \& H. Mooney), pp. 519-539. San Diego, CA: Academic Press. 